Georgia State University

ScholarWorks @ Georgia State University

World Languages and Cultures Faculty

Publications

Department of World Languages and Cultures

2016

\title{
Building bridges across institutions to recruit, educate and retain excellent language educators
}

\author{
Peter B. Swanson \\ Georgia State University, peters@tribcsp.com \\ Manuela Wagner \\ University of Connecticut, manuela.wagner@uconn.edu
}

Follow this and additional works at: https://scholarworks.gsu.edu/mcl_facpub

Part of the Other Languages, Societies, and Cultures Commons

\section{Recommended Citation}

Swanson, Peter B. and Wagner, Manuela, "Building bridges across institutions to recruit, educate and retain excellent language educators" (2016). World Languages and Cultures Faculty Publications. 56. https://scholarworks.gsu.edu/mcl_facpub/56

This Article is brought to you for free and open access by the Department of World Languages and Cultures at ScholarWorks @ Georgia State University. It has been accepted for inclusion in World Languages and Cultures Faculty Publications by an authorized administrator of ScholarWorks @ Georgia State University. For more information, please contact scholarworks@gsu.edu. 


\section{Foreign Language Annals President's Message}

Title: Building bridges across institutions to recruit, educate and retain excellent language educators.

By: Pete Swanson, Ph.D. and Manuela Wagner Ph.D.

Successful language learners in no small measure have attained that success because somewhere in their language learning biography, there was an outstanding teacher who inspired and motivated, who challenged and rewarded, and who encouraged and supported the lengthy learning process, often over many years and beyond a particular teaching relationship.

$$
\text { (Lantolf, 2009, p. 261) }
$$

In the latest edition of The Language Educator, Ken Stewart (Chapel Hill High School, NC) and I discussed the idea that the next generation of language teachers can be found in our classrooms. Research shows that between the ages of 14 and 18, adolescents begin to crystallize career aspirations (Swanson, 2013) and begin what Super (1980) referred to as making successive approximations towards finding a career path. That is, as high school students begin to consider a vocation, they appear to be open to exploring other possibilities. By offering language students the opportunity to join a Future Educator group and explore language teaching as a profession, many of these individuals may choose to become language teachers.

To that end, I asked Dr. Manuela Wagner, Associate Professor of Foreign Language Education in the Department of Literatures, Cultures, and Languages at the University of Connecticut, to collaborate on this message because of her dedication as a teacher-educator and her long history of collaborating with colleagues in schools and universities. As individuals working with world language teacher candidates in schools, we are acutely aware of the shortage of language teachers in the US and abroad. For years we have advocated for recruiting future teachers and helping them find teacher preparation programs in their geographical areas because research shows that most adults have never lived outside their home state in the US (Pew Research Center, 2008). Unsurprisingly, language teaching positions are among the most difficult to fill nationwide (Murphy, DeArmond, \& Guin, 2003). Ingersoll (2003) attributed the difficulty to fill positions largely to the teachers leaving positions before they retire. Various reasons account for the attrition, among them retirements, legislation, and the perceptions of teaching (Swanson, 2014). Among the perceptions, one's sense of efficacy in teaching languages (i.e., one's confidence) has been identified as a major reason individuals choose to leave the profession (Swanson, 2014; Swanson \& Huff, 2010).

In this President's Message, we discuss our ideas about and challenges with educating and retain excellent foreign language educators. The following questions are central to this endeavor: 1) How can we chart pathways for individuals who show an interest and passion for language education? 2) How do we then prepare them to be highly effective? 3) How can we retain teachers once they face the ever changing realities of the profession?

With respect to the first question about charting pathways for individuals who show an interest and passion for language education, an immediate challenge comes to mind. Once a 
student has either self-identified or been identified by someone else like a language teacher, it is crucial to help the person understand the various pathways to licensure and certification and what it takes to become an effective teacher. Due to the labyrinth of pathways to become a teacher, it can be confusing even for K-12 language educators and teacher educators to provide appropriate advice to foreign language teacher candidates to make an informed decision about how to ultimately become a language teacher ranging from which courses to take, planning for field experiences as well as financial planning due to the cost of becoming a teacher (e.g., content tests, edTPA). To that end, it is important to remember that teacher candidates major either in education with a concentration in foreign language teaching or perhaps major in the language with a concentration in teacher education. As majors they take general education classes in addition to taking classes for their major, and hopefully studying abroad, in order to develop further their target language proficiency and intercultural competence. In addition to helping future language teachers understand the necessary coursework, it is important for us to keep in mind the grand diversity of those who enter the profession. For example, some future teachers are recent high school graduates transitioning to college while others are considered nontraditional students who are career changers. Among these individuals are an important and promising group, heritage language speakers, who are an incredible resource that many times we overlook as we are identifying and recruiting the next generation of language teachers.

Therefore, as this diverse group of individuals enter programs, most likely they will require different pathways to optimize their educational experiences and outcomes. Transparency and availability of information about language teacher education programs is crucial and can be greatly facilitated by well-structured and continuous communication among language teacher preparation faculty. From experience, we have learned that good communication among teacher educators in various settings requires coordination and determination on part of all members in the profession. For example, in some universities teacher education is handled by schools of education. In others, teacher education programs are housed in (Liberal) Arts and Sciences (A\&S), with varying levels of collaboration between the different departments/schools. As noted by Tedick (2009), "liberal arts and education faculty and programs remain disconnected, not united in the teacher education enterprise" (p.264). Although there are some notable exceptions, there are a number of challenges for colleagues to collaborate across different settings (Wagner \& Osborn, 2010). For instance, language faculty in A\&S might not be aware of the everchanging regulations (e.g., CAEP, school district boards of education) faced by teacher education programs, which can lead to misunderstandings regarding advising and curricular collaboration. For example, if A\&S faculty are unaware of current certification and licensure regulations, misinterpretations may emerge, which in turn can negatively affect teacher candidate progress to graduation and program completion. Thus, open lines of communication are vital even though they are not always incentivized and sometimes even rendered impossible because of institutional impediments. For example, different promotion and tenure requirements make it difficult for faculty in A\&S and schools of education to collaborate on research, teaching and service.

To that end, ACTFL can serve as a mechanism for individuals spanning the K-20 spectrum to meet and discuss collaboration in order to address the teacher shortage in their own areas and foster best practices and collaboration across educational levels. ACTFL takes a clear stance on the need for collaboration between Arts and Sciences and schools of education through their ACTFL/CAEP Program Standards for the Preparation of Foreign Language Teachers. While collaboration across educational settings often means more work, it is worth it. 
Collaboration is known to strengthen an individual's position in a department and in a school. It strengthens a department as it might attract better prepared students and also produce better prepared teachers, who in turn, effect better outcomes in schools for learners.

Turning to the second question of how highly effective language teachers should be prepared, it is even more complex and also one which researchers and practitioners unsurprisingly have not been able to answer conclusively. Nevertheless, regardless that research is unable to pinpoint an exact formula that would ensure that we certify the perfect world language teacher, researchers agree that the requirements for world language educators have changed dramatically over the past decades. Kramsch (2014) notes the destabilization of "the codes, norms, and conventions that FL [foreign language] educators relied upon to help learners be successful users of the language once they had left their classrooms" (p. 214). Kubanyiova and Crookes (2016) agree with Kramsch and note that "teachers need to have knowledge that enables them to make sense of their moral and political lives as language teachers" (p.121). Understanding that the profession needs to provide resources for future and current language educators to help them situate themselves as language educators and their students as global citizens who can face the demands of the 21st century, ACTFL created a task force of experts on intercultural competence and charged the group with creating Interculturality Can-do statements. Words and Actions: Teaching Languages Through the Lens of Social Justice (Glynn, Wesely, \& Wassell, 2014) published by ACTFL is yet another resource for teachers to reflect on social justice issues in world language education (also see Osborn (2006) on Teaching World Language for Social Justice). The increasingly globalized world we live in today brings with it great opportunities for world language educators to effect positive change while also offering possible solutions to challenges we face. As members of the profession, we feel strongly that we need to put our minds together and collaborate on important questions such as how to effectively prepare world language teachers who can thrive in challenging environments.

Once our teachers are in classrooms we face yet another challenge, which leads to our third question in this message, how can we retain teachers once they face the ever-changing realities of the profession? First, we believe that mentorship following program completion is crucial. The notion of leaving first year teachers without any guidance or mentorship is alarming. We completely understand the time constraints on teacher educators, but there is a critical need to help novice educators in the first several years in the classroom. Such assistance can take several forms such as developing mechanisms to remain in contact with novice teachers, holding informal mentorship and professional development opportunities, taking novice educators with us to professional conferences, and simply taking the time to call them from time to time after the instructional day ends to lend a sympathetic ear. Such care is especially important for those who entered the profession through alternate routes to certification. Following 30 second career teachers, Haim and Andur (2016) note that there is

a need to reconsider the relationship between theoretical and practical aspects in teacher training, particularly in alternative programs which are usually shorter and hence limited in scope. The support that novice teachers receive should be contextualized in such a way as to enable them to hone their skills through guided practice in a structured environment that includes experts and peer agents (p. 23).

In an effort to retain novice language teachers regardless of the path in which they became language teachers, we developed the Language Teacher Retention Institute at Georgia 
State University last year via the Center for Urban Language Teaching and Research (2016). After conceptualizing the first week-long set of workshops in 2015, six experts with various foci related to language teaching and positive psychology (e.g., Seligman, 2002) have been collaborating to design a series of interactive professional development aimed at providing resources for language teachers to form communities of practice around themes they consider important. In the workshops, which will be presented later this month, we intentionally and transparently facilitate collaboration because we are convinced that it is not only best practice to collaborate but it is an essential skill to succeed as teachers in an increasingly complex and demanding educational climate.

As we eluded to at the start of this article, success in language teaching can often be traced back to a former teacher who served as a wonderful role model. To conclude this message, we now explore three practical and theoretical questions that we can address collaboratively in our profession to develop such inspiring language educators.

1. How can we create transparency with regard to available routes for pre-service world language teachers?

2. How can we facilitate collaboration between all languages educators (e.g., schools of education and $\mathrm{A} \& \mathrm{~S}$, schools and universities, different disciplines in language education)?

3. How can we collaborate to conduct evidence-based research which is also firmly theoretically grounded and which helps us address pressing questions in our profession? It is important to note that this research should be easily accessible to a wide audience.

Attempting to answer these questions, of course, requires colleagues with different backgrounds to collaborate and communicate with each other. As noted earlier, ACTFL takes the recruitment, preparation, and retention of language teachers seriously, and the 2016 ACTFL Convention in Boston can serve as a nexus for collaboration in order to address the teacher shortage.

\section{References}

Center for Urban Language Teaching and Research. (2016). Language teacher retention institute. Georgia State University. Available from, http://cultr.gsu.edu/research/teacherretention/language-teacher-retention-project/

Glynn, C., Wesely, P., \& Wassell, B. (2014). Words and actions: Teaching languages through the lens of social justice. Alexandria, VA: ACTFL.

Haim, O., \& Amdur, L. (2016). Teacher perspectives on their alternative fast-track induction. Teaching Education. DOI: 10.1080/10476210.2016.1145204

Holland, J. L. (1985). Making vocational choices. Englewood Cliffs, NJ: Prentice-Hall.

Ingersoll, R. (2003). Is There Really a Teacher Shortage? CPRE Research Reports. Available from, http://repository.upenn.edu/cpre_researchreports/37 
Kubanyiova, M., \& Crookes, G. (2016). Re-envisioning the roles, tasks, and contributions of language teachers in the multilingual era of language education research and practice. The Modern Language Journal, 100(S1), 117-132.

Lantolf, J. P. (2009), Knowledge of Language in Foreign Language Teacher Education. The Modern Language Journal, 93(2), 270-274. doi: 10.1111/j.1540-4781.2009.00860_4.x

Murphy, P., DeArmond, M., \& Guin, K. (2003). A national crisis or localized problems? Getting perspective on the scope and scale of the teacher shortage. Education Policy Analysis Archives, 11(23). doi: 10.14507/epaa.v11n23.2003

Osborn, Terry A. (2006). Teaching world languages for social justice: A sourcebook of principles and practices. Mahwah, NJ: Lawrence Erlbaum Associates, Inc.

Pew Research Center. (2008). American mobility: Who moves? Who stays put? Where's home? Available from, http://www.pewsocialtrends.org/files/2010/10/Movers-and-Stayers.pdf

Seligman, M.E.P. (2002). Authentic happiness: Using the new positive psychology to realize your potential for lasting fulfillment. New York, NY: Free Press.

Super, D. E. (1990). A life-span, life-space, approach to career development. In D. Brown \& L. Brooks (Eds.), Career choice and development (2nd ed., pp. 197-261). San Francisco: JosseyBass.

Swanson, P. (2013). Identifying and recruiting language teachers: A research-based approach. Charlotte, NC: Information Age Publishing.

Swanson, P. (2014). The power of belief: Spanish teachers' sense of efficacy and student performance on the national Spanish exams. Hispania, 97(1), 5-20.

Swanson, P., \& Huff, R. (2010). Georgia's rural foreign language teachers' sense of efficacy and how it relates to teacher attrition. The Rural Educator, 31(3), 16-29.

Wagner, M., \& Osborn, T. A. (2010). When worlds collide: Liberal arts and college of education faculty co- teaching the methods courses. In J. Davis (Ed.), World language teacher education: Transitions and challenges in the 21st century (pp. 3-16). Charlotte, NC: Information Age Publishing. 